\title{
Non-syndromic double lip
}

\author{
Ravi Prakash Sasankoti Mohan, ${ }^{1}$ Sankalp Verma, ${ }^{2}$ Amit Singh, ${ }^{2}$ Udita Singh ${ }^{2}$
}

$10 M D R$, Kothiwal Dental College, Moradabad, Uttar Pradesh, India

${ }^{2}$ Department of Oral Medicine \& Radiology, Kothiwal Dental College \& Research Center, Moradabad, Uttar Pradesh, India

\section{Correspondence to} Dr Ravi Prakash Mohan, sasan_ravi@rediffmail.com
To cite: Mohan RPS,

Verma S, Singh A, et al.

BMJ Case Rep Published

online: [please include Day

Month Year] doi:10.1136/

bcr-2013-008664

\section{DESCRIPTION}

A 57-year-old man reported to the outpatient department with the chief compliant of deformed upper lip which was present since birth. He denied any complaints other than cosmetic ones. On examination, an extra fold of redundant tissue was present on the inner surface of the upper lip. The overlying mucosal tissue appeared intact and smooth with no palpable masses or surface changes (as seen in figure 1). There were no other associated congenital abnormalities. Thus, provisional diagnosis of congenital bilateral upper double lip was made.

Double lip may develop in association with Ascher's syndrome which consists of the triad of blepharochalasis, non-toxic thyroid enlargement and double lip. ${ }^{2} 2$ The association of congenital double lip with other abnormalities such as bifid uvula and cleft palate has also been reported. Another uncommon acquired condition is cheilitis glandularis, an inflammatory hyperplasia with varying degrees of inflammation of the lower labial salivary glands. ${ }^{3}$

In conclusion, treatment of congenital double lip is indicated when the excess tissue interferes with mastication and speech or is of aesthetic concern to the patient.

\section{Learning point}

As syndromic double lip is associated with Ascher's syndrome, one should look for other features associate of Ascher's syndrome.

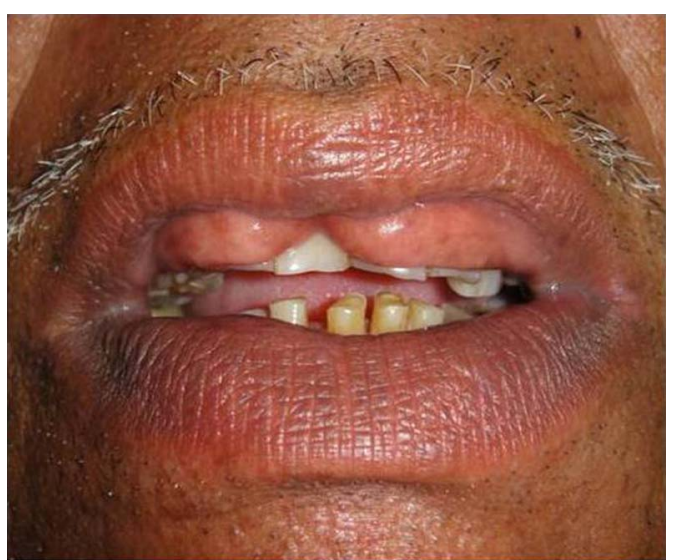

Figure 1 Photograph of extraoral view showing an extra fold of redundant tissue on the inner surface of the upper lip with no palpable masses or surface changes.

\section{Competing interests None.}

Patient consent Obtained.

Provenance and peer review Not commissioned; externally pee reviewed.

\section{REFERENCES}

1 Martins Wd, Westphalen FH, Sandrin R, et al. Congenital maxillary double lip: review of the literature and report of a case. J Can Dent Assoc 2004;70:466-8.

2 Chidzonga MM, Mahomva L. Congenital double lower lip: report of a case. Int J Paediatr Dent 2006;16:448.

3 Parmar RC, Muranjan MN. A newly recognized syndrome with double upper and lower lip, hypertelorism, eyelid ptosis, blepharophimosis and third finger clinodactyly. Am J Med Genet A 2004:124A:200-1.

Copyright 2013 BMJ Publishing Group. All rights reserved. For permission to reuse any of this content visit http://group.bmj.com/group/rights-licensing/permissions.

BMJ Case Report Fellows may re-use this article for personal use and teaching without any further permission.

Become a Fellow of BMJ Case Reports today and you can:

- Submit as many cases as you like

- Enjoy fast sympathetic peer review and rapid publication of accepted articles

- Access all the published articles

- Re-use any of the published material for personal use and teaching without further permission

For information on Institutional Fellowships contact consortiasales@bmjgroup.com

Visit casereports.bmj.com for more articles like this and to become a Fellow 